\title{
The enduring effects of the Great Recession on wage growth in the United States
}

\author{
Dean Baker \\ Center for Economic and Policy Research, Washington, DC, USA
}

Real wages in the United States have continued to stagnate in the years since the end of the Great Recession. This paper attributes this stagnation directly to the prolonged period of high unemployment. It notes research showing that the only period of sustained wage growth for most of the workforce in the last 3 decades was the period of unusually low unemployment in the late 1990s. Given current economic and political trends, it is unlikely that we will again see a level of unemployment low enough to support broad-based real wage growth in the near future.

Keywords: unemployment, wages, hysteresis

JEL codes: $E 66, E 62, E 31$

\section{INTRODUCTION}

Workers in the United States have fared notably worse than workers in other wealthy countries over the last 3 decades. Over most of this period, wages for the median worker have barely kept pace with inflation. The only period in which most workers saw a sustained period of real wage growth was during the late 1990s boom. As bad as the situation had been prior to the Great Recession, it has sharply deteriorated in the 6 years since the downturn began. There is a real risk that workers could face a decade of widespread unemployment and underemployment, with wages at best keeping pace with inflation.

Section 2 of this paper outlines the pattern of inequality facing workers in the United States in the decades prior to the onset of the Great Recession. The upward redistribution was primarily from workers at the middle and bottom to those at the top. Section 3 discusses the situation since the onset of the Great Recession and the risks of a prolonged period of high unemployment and stagnant wages. Section 4 concludes.

\section{WAGES AND INEQUALITY IN THE UNITED STATES}

In the decades from 1979 to 2007 there was almost no growth in the median wage for US workers. The real wage of the median male worker fell by roughly 5 percent over this period, while the median female real wage rose by roughly 25 percent, as shown in Figure 1.

However, since women started from a lower level and grew substantially as a share of the workforce over this period, there was almost no change in the overall median across this 28-year span. This is a sharp departure from the prior 3 decades in which wages rose largely in step with overall productivity growth.

There are a number of factors that are widely cited to explain the divergence that began in the 1980s. First, unions became much weaker, both as a result of changes in the economy and also as deliberate policy. The severe recession at the start of the 1980s hit manufacturing, with 


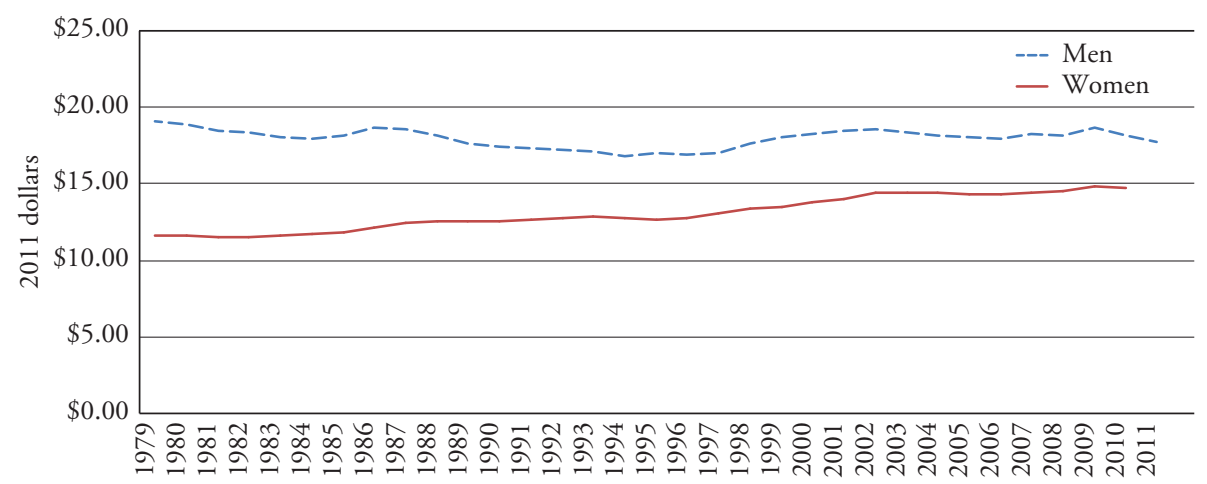

Source: Economic Policy Institute.

\section{Figure 1 Median hourly wages}

the most heavily unionized sector of the economy hit especially hard. The run-up in the dollar that was associated with the high-interest rates of the period led to a large trade deficit that compounded the effect of the recession. The Reagan administration also took a notably more aggressive stance to unions than either the Democratic or Republican administrations that preceded it. This meant a more hostile National Labor Relations Board and also the introduction of the practice of firing striking workers following a strike of air traffic controllers. While a law prohibiting strikes by federal employees facilitated this firing, the private sector was quick to embrace the tactic. Following Reagan's action, several large firms fired strikers and many others made the threat of doing so. The fear of dismissal made the strike a much less effective mechanism for unions.

The deregulation of several large industries in which workers typically enjoyed higher wages - telecommunications, trucking, and air lines - also put downward pressure on wages. The minimum wage was also allowed to drop sharply in real terms, remaining flat in nominal terms between 1982 and 1990. (In the years from 1938 to 1968 the minimum wage tracked overall productivity growth.) The government pursued a trade policy over the last 3 decades in which manufacturing workers were deliberately exposed to international competition while highly educated professionals like doctors and lawyers were largely protected.

These and other policy developments had the predictable effect of shifting income from workers at the middle and the bottom of the wage distribution to those at the top. In contrast to the pattern in many other wealthy countries, there was actually little redistribution from labor to capital over the bulk of the period since 1980 . Figure 2 shows average real compensation, median real compensation, and productivity growth since $1973 .^{1}$

As can be seen in the figure, there is little divergence between productivity and the average wage until 2000. Most of the gap between productivity and median compensation is explained by a growing gap between average compensation and median compensation.

1. The measure of productivity used in Figure 2 is a net measure that uses a CPI deflator (see Baker 2007). This makes it directly comparable to the measures of wage growth shown in the chart. The measure for median compensation assumes that the percentage of compensation going to non-wage compensation for the median worker is the same as for the average worker. 


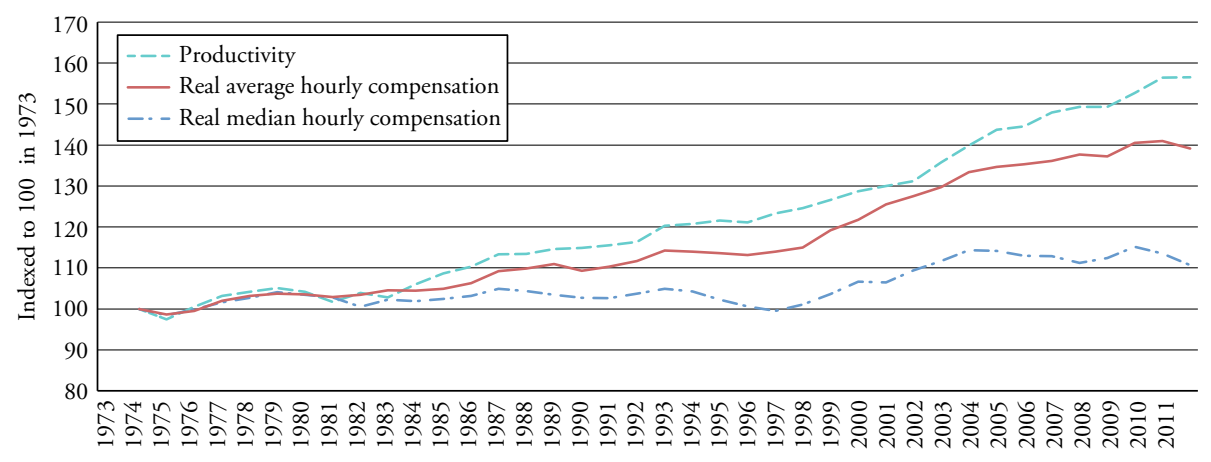

Figure 2 Change in hourly productivity, real average hourly compensation, and median compensation, 1973-2011

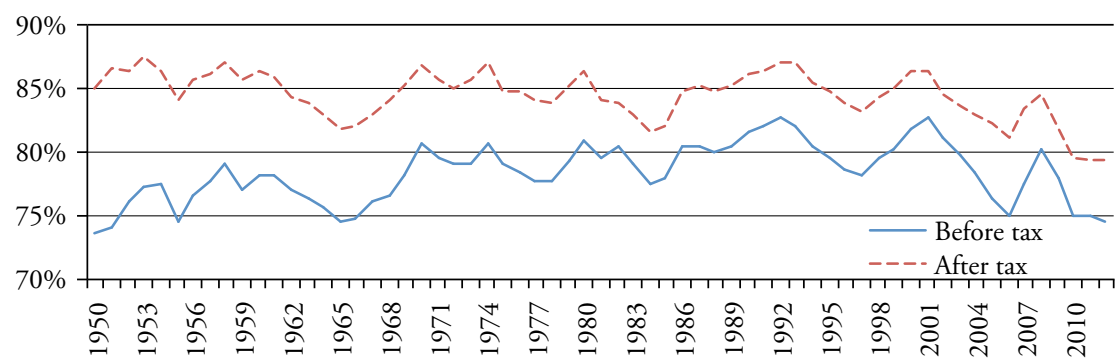

Figure 3 Labor share of corporate income

This is a case where workers at the high end of the income distribution - mostly the top 1 or 2 percent - were achieving substantial wage gains while those at the middle and bottom were essentially seeing no gains. The one exception to this story is the period at the end of the 1990s when median compensation did rise substantially. In the years from 1997 to 2004 , median real compensation rose by almost 15 percent. This increase in wages is associated with an uptick in productivity growth, but more importantly with a drop in the unemployment rate to levels not seen since the early 1970 s.

The other notable point in Figure 2 is that there is a growing divergence between productivity and the average wage, beginning in 2004 and continuing in the most recent data. This is a situation where there is a shift from labor income to capital income, a point that can be seen more clearly if we look at labor shares directly, as shown in Figure $3 .^{2}$

Figure 3 shows labor share of income including and excluding corporate income taxes. The after-tax share is worth examining separately, as some economists contend that the corporate income tax is primarily paid out of wages. If this were true, then movements in the before-tax share could simply reflect changes in the corporate tax rate. Since corporate taxes declined as a share of profits over this period, if corporate taxes came out of wages we should have seen a rise in the labor share of before-tax income. Of course, this is not the pattern in the data. The labor share of corporate income shows no clear pattern until the last decade. As noted above, the labor share of income begins to decline

2. Figure 3 shows labor share of net income in the corporate sector. It excludes both depreciation and indirect business taxes from the denominator. 
sharply in the last decade, and in 2012 - the last year for which full data is available - the labor share of after-tax income was lower than at any point since before 1950. Labor's share of before-tax income was still slightly above the lows of the early 1950s and the low point hit in 1965 .

There are two plausible explanations for the shift from wages to profits at the start of this period. First, the trade deficit was exploding during these years. This was undermining the bargaining power of workers in manufacturing. This sector continued to see job growth through 2007, even though the economy was adding jobs at a relatively healthy pace after 2004. The other reason for a shift from wages to profits in the years prior to the downturn was a sharp jump in the world price of oil. While most of the oil consumed in the United States is imported, close to 40 percent was domestically produced. And the jump in oil prices also led to a jump in the price of coal and natural gas, almost all of which was produced domestically. Therefore the higher price of energy in these years largely implied a transfer from workers to corporate profits in the energy sector.

However, this initial redistribution from wages to profits was dwarfed by the redistribution that followed in the wake of the Great Recession. Real average hourly compensation has just barely kept pace with inflation since the start of the downturn. ${ }^{3}$ Capital has enjoyed virtually all of the benefits of productivity growth. At the moment, there seems little likelihood that this situation will change any time in the near future. While job growth is somewhat exceeding the growth of the potential labor force, the gap is relatively small. If job growth continues at its pace of the last 3 years, the labor market will not return to pre-recession conditions until the end of the decade. ${ }^{4}$

While a tightening of the labor market is essential for workers to gain enough bargaining power to be able to share in the gains of growth, it is even more important for workers at the middle and bottom of the wage distribution. Table 1 shows the impact of unemployment on wages at different points of the income distribution. ${ }^{5}$

The data in Table 1 shows the relationship between unemployment and real wages, controlling for age, education, gender, and race. It shows a highly significant negative relationship between unemployment and wage levels for all the groups in the sample. The impact is strongest at the lower end of the wage distribution. The rate of unemployment also seems to have more impact on the wages of men than women. This analysis is very much consistent with the experience of workers in the bottom half of the wage distribution in the late 1990s. These workers experienced sustained wage growth for the first time since the 1970s.

This analysis also suggests that the higher rates of unemployment experienced in the years since 1980 may have played a substantial role in the upward redistribution of wage income in this period. Even using the Congressional Budget Office's estimates of

3. A sharp slowing of health care costs may explain some of the slowing in compensation growth. The rate of growth in health care costs had been exceeding GDP growth by almost 2 percent annually in the years leading up the Great Recession. Since 2008, the rate of growth of health care costs has been virtually the same as the rate of growth of GDP. While health care insurance and other employer-provided benefits may come out of wages in the long term, in the short term a spike in costs is likely to be absorbed by an employer as would be an unexpected falloff in cost growth. The weak labor market conditions following the Great Recession likely made it easier for employers to capture most of the benefit from the slower growth of health care costs.

4. The gap between the trend rate of growth of employment and the actual level of employment as of December 2013 was over 8 million. The exogenous growth in the size of the labor force is roughly 90000 a month. The average rate of job growth in 2011-2013 was 180000 per month. This implies that the gap is closing at the rate of 90000 . At this pace, the gap will not be closed until 2021 .

5. This is a synthetic cohort analysis using the Current Population Survey. A fuller explanation can be found in Baker/Bernstein (2013). 
Table 1 Real hourly wages and unemployment, year-of-birth cohorts, 1979-2011

\begin{tabular}{|c|c|c|c|c|c|c|c|c|c|}
\hline \multirow[b]{2}{*}{ Wage percentile: } & \multicolumn{3}{|c|}{ All } & \multicolumn{3}{|c|}{ Men } & \multicolumn{3}{|c|}{ Women } \\
\hline & 20 th & 50th & 90th & 20th & 50 th & 90th & 20th & 50 th & 90th \\
\hline $\begin{array}{l}\operatorname{Ln}(u, t-1) \\
\text { (s.e.) }\end{array}$ & $\begin{array}{r}-0.050 \\
0.007\end{array}$ & $\begin{array}{r}-0.039 \\
0.009\end{array}$ & $\begin{array}{r}-0.027 \\
0.013\end{array}$ & $\begin{array}{r}-0.064 \\
0.010\end{array}$ & $\begin{array}{r}-0.059 \\
0.011\end{array}$ & $\begin{array}{r}-0.041 \\
0.013\end{array}$ & $\begin{array}{r}-0.044 \\
0.006\end{array}$ & $\begin{array}{r}-0.026 \\
0.008\end{array}$ & $\begin{array}{r}-0.021 \\
0.013\end{array}$ \\
\hline $\begin{array}{l}\text { Trend } \\
\text { (s.e.) }\end{array}$ & $\begin{array}{l}0.008 \\
0.000\end{array}$ & $\begin{array}{l}0.012 \\
0.000\end{array}$ & $\begin{array}{l}0.021 \\
0.001\end{array}$ & $\begin{array}{l}0.008 \\
0.001\end{array}$ & $\begin{array}{l}0.013 \\
0.001\end{array}$ & $\begin{array}{l}0.023 \\
0.001\end{array}$ & $\begin{array}{l}0.008 \\
0.000\end{array}$ & $\begin{array}{l}0.013 \\
0.000\end{array}$ & $\begin{array}{l}0.021 \\
0.001\end{array}$ \\
\hline $\begin{array}{l}N \\
\text { Groups }\end{array}$ & $\begin{array}{r}320 \\
20\end{array}$ & $\begin{array}{r}320 \\
20\end{array}$ & $\begin{array}{r}320 \\
20\end{array}$ & $\begin{array}{r}320 \\
20\end{array}$ & $\begin{array}{r}320 \\
20\end{array}$ & $\begin{array}{r}320 \\
20\end{array}$ & $\begin{array}{r}320 \\
20\end{array}$ & $\begin{array}{r}320 \\
20\end{array}$ & $\begin{array}{r}320 \\
20\end{array}$ \\
\hline
\end{tabular}

Source: Baker/Bernstein (2013).

the NAIRU as a reference point, unemployment has been substantially higher in the years since 1980 than in the 3 decades prior to 1980 . From 1980 to 2012 the unemployment rate averaged 1.0 percentage point above the NAIRU. By contrast, in the years from 1949 to 1979 the unemployment rate averaged 0.5 of a percentage point less than the estimated NAIRU. The gap in average unemployment rates would be even larger if we just used levels since the estimated NAIRU was consistently higher in the period after 1980.

The strong evidence for a link between unemployment and wage growth for workers at the middle and bottom end of the wage distribution is simultaneously encouraging and discouraging. It is encouraging because it indicates that we know how to at least partially address the wage inequality that has developed over the last 3 decades. If we can sustain the sort of low unemployment rates experienced in the late 1990s, most workers can expect to share in the gains from growth. This doesn't mean that there will not still be factors contributing to inequality, such as de-unionization and trade, but the impact of these other factors can be substantially lessened in an economy that maintains near-full employment levels of output.

However, the flipside of this story is that the United States does not seem likely to experience low levels of unemployment any time in the near future. As noted earlier, the recent rate of growth will leave the US economy operating well below full employment for the rest of the decade. Unfortunately, there is little political prospect for measures that will substantially increase the rate of growth in the foreseeable future. This is in spite of the fact that the evidence that stimulus will boost growth continually gets stronger.

At the start of the downturn in 2008, there was perhaps a credible argument that stimulus could be contractionary and fiscal consolidation expansionary, reversing the standard Keynesian story. The evidence of this anti-Keynesian position was provided largely by a series of papers by Alberto Alesina (see, for example, Alesina/Ardagna 1998; Alesina et al. 2012). Part of this anti-Keynesian argument was a traditional crowding out view. Higher budget deficits would lead to higher interest rates. This would in turn reduce investment and government spending, and also net exports, if the country had a freely floating exchange rate. However, in addition to this standard argument, Alesina also put forward an argument based on confidence in the private sector. ${ }^{6}$

The nature of this argument was that stimulus led to larger deficits and debt, thereby leading to a drop in private sector confidence. The impact of this loss of confidence on investment and consumption spending would more than offset any increase in demand

6. This argument is put forward most clearly in Alesina et al. (2012). 
from the stimulus. From this standpoint, austerity could be expansionary. The reduction in deficits would give private actors confidence that the government was committed to a sustainable fiscal path. Furthermore, Alesina argues that it is important that consolidation occur primarily through cuts in spending rather than tax increases. Tax increases can reduce expected after-tax profits which would discourage investment. Furthermore, spending cuts - especially if they are focused on areas like pensions and health care spending, and other social welfare spending - can show that the government is prepared to go against popular sentiment to push a pro-business agenda. This provides a further boost to confidence. In addition, when these cuts actually go into effect, by reducing welfare state supports for people who are not working, they can force more people into the labor market, putting downward pressure on wages.

This argument was embraced by proponents of austerity in many countries. However, the evidence to support it was shown to be considerably weaker in further research. In particular, an analysis by the International Monetary Fund (2010) re-examined the evidence of the impact of fiscal consolidations on growth. Rather than using a cyclically-adjusted budget deficit, as Alesina and most other researchers had done, the IMF analysis relied on an 'action-based' set of fiscal consolidations in the OECD countries from 1980 to 2009. The advantage of this action-based data set was that it distinguished between changes in fiscal policy that were the result of deliberate policy, such as planned spending cuts or tax increases, and changes that were the result of cyclical movements that were imperfectly captured by standard cyclical adjustments. The most obvious item in this category is changes in tax collections that are the result of capital gains. There are several easily identifiable instances in which the standard measures of cyclically adjusted budget deficits show substantial cuts in the deficit when policy was either neutral or expansionary. This sort of mis-measurement would lead to serious errors in estimating the impact of fiscal consolidation.

Using this action-based data set, the analysis found that fiscal consolidations were in general contractionary, at least in the short term. This was especially likely to be the case when the consolidation occurred when the economy was operating substantially below capacity. Furthermore, the analysis found that the asymmetric response to consolidations based on spending cuts and tax increases was primarily attributable to differential responses by central banks. Central banks tended to respond to cuts in spending with more expansionary monetary policy than they did with tax increases. Controlling for central bank responses, there was little difference in how tax increases and spending cuts affected the economy. ${ }^{7}$ The analysis also showed that much of the expansionary impact associated with fiscal consolidations came about through the foreign sector, with drops in currency values leading to large increases in net exports.

These findings are especially important in the context of the current crisis. In most of the wealthy countries, the short-term interest is already up against the zero bound. There is little reason to expect an asymmetric response or indeed any substantial response from

7. It is worth noting that there is a serious flaw in the construction of the IMF's action-based data set. It has an asymmetric treatment of planned spending and tax increases in areas like public pension and health care spending. If tax increases are scheduled to cover the increase in costs in these programs, they are treated as action-based policy in the data set. However, the projected increases in spending associated with predictable changes in demographics and health care costs are not treated as planned. In the case of the United States, this can be shown to lead to measures of planned cuts in spending that are much larger than the cuts in spending that actually took place. This would lead estimates of the impact of changes in spending on GDP to understate the actual impact, as they are assuming much larger cuts in spending than actually took place (Baker/Rosnick 2014.) 
central banks to budget cuts. Conventional monetary policy has reached its limits and it's not clear that the willingness of central banks to experiment with unorthodox polices is in any way contingent on lower deficits. Furthermore, an improved trade balance from a lower-valued currency will not be possible in the eurozone countries. For these reasons, it is not plausible that fiscal consolidation can be expansionary in current economic conditions.

A later IMF paper relating forecast errors to fiscal policy changes further reinforces the view that fiscal consolidation in current economic conditions will be contractionary (Blanchard/Leigh 2013). The paper regressed the forecast error in IMF forecasts from 2010 against the extent of fiscal consolidation. It found a highly significant relationship between the size of the forecast error and the extent of fiscal consolidation, with the overestimates of growth increases in proportion to the degree of planned consolidation. This implies that the IMF's country models had systematically underestimated the extent to which consolidation would be contractionary in current economic conditions. It is worth noting in this respect that there was no relationship between the size of the forecast error and the degree of planned consolidation in the decade prior to the crisis.

These papers, along with much other research, solidly support the case that fiscal stimulus can be expansionary in current economic conditions. ${ }^{8}$ The one remaining argument against stimulus to boost demand and reduce unemployment were concerns related to the ReinhartRogoff analysis claiming countries were coming up against debt limits where further increases in the debt-to-GDP ratio risked throwing them into a prolonged period of slow growth. In their original work on this topic, Reinhart and Rogoff had pegged a 90 percent debt-to-GDP ratio as the key cutoff point, above which growth slowed sharply. With most wealthy countries near or above this threshold, this concern could provide a real argument for avoiding further stimulus and focusing on fiscal consolidation.

However, further analysis uncovered errors in the original paper (Herndon et al. 2013). While there is a negative relationship between debt-to-GDP ratios and growth rates, this negative relationship exists at all levels of debt-to-GDP. This means current debt levels provide no greater basis for concern over increasing debt than the lower debt levels in the pre-crisis period. Furthermore, the Reinhart-Rogoff analysis did not examine causality. There is, of course, a mechanical relationship between debt-to-GDP ratios and growth, in the sense that, with the same deficit levels, a country with a fast-growing economy will have a lower debt-to-GDP ratio than a slow-growing economy. Subsequent work which did examine causality found the direction of causation ran overwhelmingly from slow growth to high debt rather than in the opposite direction. In other words, countries that were doing poorly tended to accumulate large amounts of debt. There is little evidence that countries do poorly because they accumulate large amounts of debt.

In the current context, a simple comparison of debt-to-GDP ratios with interest rates on long-term debt for non-eurozone economies shows no relationship, as illustrated in Figure 4.

Japan, which has by far the highest debt-to-GDP ratio of any wealthy country, has consistently maintained a long-term interest rate of less than 1.0 percent. (The rates shown in Figure 4 are nominal, but the differences in inflation rates are not large enough to change the picture in any noticeable way.) In short, there is little reason to believe that any of the non-eurozone countries are facing any near-term borrowing constraints. Insofar as eurozone countries do face constraints, this is due to a policy choice, not an intrinsic economic constraint.

8. Gechert (2012) provides a useful assessment of the research on fiscal stimulus in a meta-analysis. This paper examines 105 studies of fiscal multipliers. The analysis shows that most studies find large and significant coefficients for multipliers on government spending. 


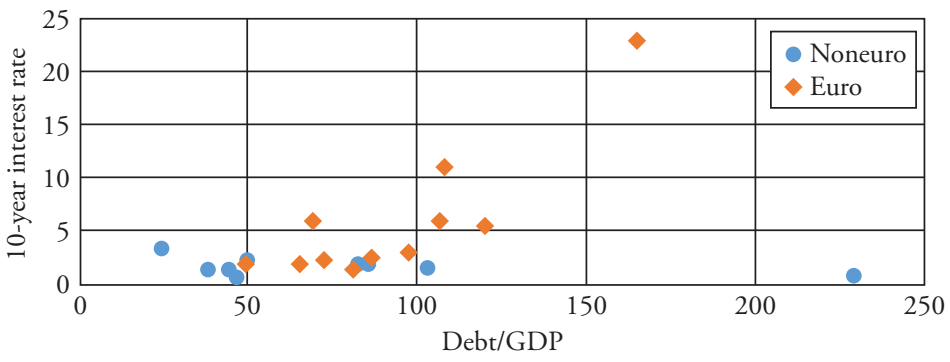

Figure 4 Debt and interest rates

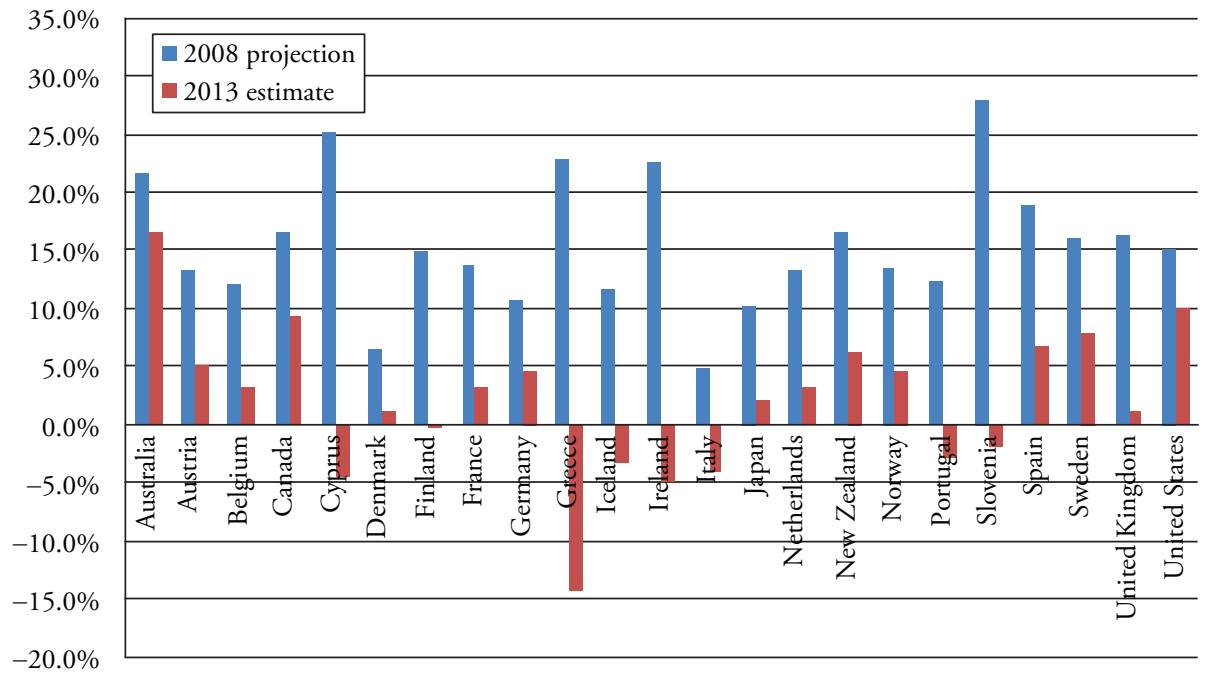

Source: IMF and author's calculations.

Figure 5 Real GDP growth, 2007-2013

\section{THE LONGER-TERM OUTLOOK}

If there is growing evidence that fiscal stimulus can increase growth and reduce unemployment, there is also growing evidence that countries are facing a substantial price for allowing their economies to operate at levels of output far below potential GDP for long periods of time. Most official forecasters have sharply lowered their estimates of potential GDP in the years since the crisis. The Congressional Budget Office's most recent estimates of potential GDP for the US economy in 2014 are more than 6 percentage points below their projections from 2007. A recent paper from the Federal Reserve Board put the loss in potential output as a result of the prolonged downturn at more than 7 percent of GDP (Reifschneider et al. 2013). The IMF's most recent projections of potential GDP are far below its projections from before the crisis as shown in Figure 5. For the hardest-hit countries, such as Greece, Cyprus, and Spain, the gap between the 2008 projections and the current estimates are more than 20 percent. 
The reason for the lowering of projections comes primarily from three sources. First, lower levels of output are associated with less private and public investment. As a result, the capital stock is considerably smaller in 2014 than it was projected to be in 2008 . Second, the downturn and the financial crisis have made it more difficult for new businesses to get started and to grow. Since new firms are major sources of innovation, economies have seen considerably less multi-factor productivity growth in the years since the crisis. Finally, after long periods of unemployment workers lose skills and become out of touch with the labor force. This can leave many workers unemployable even after the economy recovers.

While the estimates of the loss in potential GDP are still somewhat speculative, and the IMF projections are particularly crude, it is virtually certain that economies are facing substantial losses in potential output as a result of allowing the downturns to drag on for long periods of time. This means that the costs of this downturn will be felt for many years to come, especially if measures are not taken to boost growth from its current path.

\section{CONCLUSION}

This paper discussed the relationship between wage growth and unemployment in the United States. It showed that most workers had not shared in the benefits of productivity growth in the years after 1980 with the exception of the years of low unemployment at the end of the 1990s. During these years there was strong wage growth at all points along the wage distribution, with the strongest gains going to workers at the bottom end of the distribution.

The situation for workers worsened notably following the 2001 recession. While the wage share of corporate income had remained reasonably constant in the 1980s and 1990s, in the last decade and especially since the 2008 downturn there has been a sharp redistribution from wages to profits, with almost all of the gains from growth going to higher profits. The most recent data from 2013 show wages still just keeping pace with inflation. Until labor markets tighten considerably further, this situation is not likely to change appreciably.

Section 3 briefly noted the growing body of evidence supporting the view that fiscal stimulus can boost growth in current economic conditions. If this had been a debatable point at the start of the downturn; that is no longer the case at present. The countries that have adopted the most contractionary fiscal policies have seen the weakest growth. Furthermore, there is little reason for concerns about running up against debt limits. The negative relationship between debt-to-GDP ratios and growth is driven primarily by the fact that slow growth leads to higher debt. At present, in countries that have their own currency, there is no relationship between debt-to-GDP ratios and long-term interest rates, implying that there is no immediate basis for concern over hitting debt ceilings.

Finally, there is a growing body of research indicating that countries are paying a longterm price in the form of lower potential GDP by allowing their economies to remain far below potential output for long periods of time. The drop in potential GDP is due largely to workers losing skills and permanently dropping out of the labor force; however, reduced public and private investment also are important factors.

In short, there seems little economic reason not to engage in more expansionary fiscal policies to boost growth and reduce unemployment. The obstacles are on the political side. The advanced economies are likely to pay a substantial economic price for this political choice.

\section{REFERENCES}

Alesina, A., Ardagna, S. (1998): Tales of fiscal adjustment, in: Economic Policy, 13(27), 487-545.

Alesina, A., Favero, C., Giavazzi, F. (2012): The output effect of fiscal consolidations, Working paper no. w18336, Cambridge, MA: National Bureau of Economic Research. 
Baker, D. (2007): The productivity to paycheck gap: what the data show, Working paper, Washington, DC: Center for Economic and Policy Research.

Baker, D., Bernstein, J. (2013): Getting Back to Full Employment: A Better Bargain for Working People, Washington, DC: Center for Economic and Policy Research.

Baker, D., Rosnick, D. (2014): Stimulus and fiscal consolidation, Working paper, Washington, DC: Center for Economic and Policy Research.

Blanchard, O., Leigh, D. (2013): Growth forecast errors and fiscal multipliers, IMF Working Paper No. 13/1, International Monetary Fund.

Gechert, S. (2012): What fiscal policy is most effective? A meta regression analysis, Working paper no. 117, Macroeconomic Policy Institute (IMK).

Herndon, T., Ash, M., Pollin, R. (2013): Does high public debt consistently stifle economic growth? A critique of Reinhart and Rogoff, Political Economy Research Institute report, University of Massachusetts.

International Monetary Fund (2010): World Economic Outlook: October 2010, International Monetary Fund.

Reifschneider, D., Wascher, W.L., Wilcox, D. (2013): Aggregate supply in the United States: recent developments and implications for the conduct of monetary policy, Paper presented at the 14th Jacques Polak Annual Research Conference, International Monetary Fund, Washington, DC, November. 